\title{
THE EFFECTIVENESS OF COMBINATED ANTIHYPERTENSIVE TREATMENT IN PATIENTS WITH ESSENTIAL HYPERTENSION OF THE II-ND STAGE DEPENDING ON THE TYPE OF DAILY BLOOD PRESSURE PROFILE AND THE TYPE OF REMODELLING OF THE LEFT VENTRICLE
}

DOI: 10.36740/WLek202001108

\author{
Tetiana Y. Niushko ${ }^{1}$, Olena K. Tarasiuk' ${ }^{1}$, Yulia K. Sikalo² \\ 'NATIONAL PIROGOV MEMORIAL MEDICAL UNIVERSITY, VINNYTSIA, UKRAINE \\ 2KHARKIV NATIONAL MEDICAL UNIVERSITY, KHARKIV, UKRAINE
}

\begin{abstract}
The aim: To evaluate the dynamics of structural and functional parameters of the heart, vessels in patients with hypertension of the II-nd stage under the influence of combined antihypertensive treatment depending on the type of the left ventricle remodelling and the profile of blood pressure (BP).

Materials and methods: The study involved 110 patients with hypertension of the II-nd stage. The ambulatory blood pressure monitoring, echocardiography and doppler examination of the shoulder arteries were performed. Initial treatment included bisoprolol, lisinopril, hydrochlorothiazide. With impossibility of BP lowering to the target level, amlodipine has been added.

Results: higher levels of BP in the "non-dipper" patients have led to the development of more pronounced changes in the heart and vessels compared with "dipper" patients. Three-component therapy was effective in patients with lower BP. The prescription of amlodipine has been found to be necessary for the majority of "non-dipper" patients and for the minority of "dipper". Combined therapy effectively controlled the BP at the level of the target and contributed to a decrease in the displays of remodelling of the heart and blood vessels.

Conclusions: combined therapy used for 6 months reduces displays of disadaptive heart and vascular remodelling, diastolic, endothelial dysfunction. With the lack of efficacy of the therapy, which includes bisoprolol, lisinopril, hydrochlorothiazide, the adding of amlodipine to it can reach the target level of BP
\end{abstract}

KEY WORDS: arterial hypertension, antihypertensive therapy, diastolic dysfunction, endothelial dysfunction

Wiad Lek. 2020;73(1):46-51

\section{INTRODUCTION}

Nowadays arterial hypertension $(\mathrm{AH})$ is one of the most important risk factors for the development of cardiovascular complications and mortality in the world, as it has become a medical and social problem. In 2016, about 12 million patients with $\mathrm{AH}$ were registered in Ukraine. Among the illnesses of the cardiovascular system (CVS) in the adult population, this indicator has reached $46.8 \%$. High prevalence, disabling and fatal consequences of the illness require the search for ways to maximise the coverage of effective treatment of this population. Despite the availability of powerful opportunities for medical correction of high BP, the results of international and domestic studies indicate an inadequate level of its control. In modern strategic positions on the prevention and treatment of hypertension the emphasize the need to achieve the target level of BP, that reduces the risk of complications. Only $20 \%$ of the Ukrainians have a level that corresponds to the target. Increased BP affects the CVS, because excessive prolonged pressure on the target organs leads to pathological remodelling of the heart and blood vessels.
This, first of all, is displayed by the left ventricular hypertrophy (LVH), the intima-media thickness (IMT) with subsequent functional deficiency of CVS, characterised by the development of diastolic dysfunction (DD) and endothelial dysfunction (ED). It has been defined, that LVDD is independent of the level of AP by the predictor of the prognosis worsening in patients with hypertension. The development of $\mathrm{AH}$ is a consequence of interaction of complex mechanisms, among which the leading role is played by ED, which is displayed in a violation of the ratio of factors of vasoconstriction and vasodilation. An important causal-consequential relationship between ED and the development and progression of $\mathrm{AH}$ has been proved in numerous studies. Increased BP is a consequence of various mechanisms responsible for its regulation (humoral, neuroendocrine systems, peripheral resistance, cardiac output, etc.). In this regard, the use of combined antihypertensive treatment, which acts on different parts of the AH pathogenesis, is the most effective $[1,2,3,4]$. When prescribing combinative therapy for BP correction, the most effective therapy is the combination of the drug 
acting on renin-angiotensin-aldosterone, sympathoadrenal systems, blocker of calcium channels (BCC), and thiazide diuretic $[5,6]$.

\section{THE AIM}

To evaluate the dynamics of structural and functional parameters of the heart, vessels in patients with hypertension of the II-nd stage under the influence of combined antihypertensive treatment depending on the type of the left ventricle remodelling and the profile of BP.

\section{MATERIALS AND METHODS}

The study involved 110 patients (70 women, 40 men) with hypertension of the II-nd stage, hypertensive heart, chronic heart failure (HHF) of the 0-I stage (average age 54.19 \pm 0.89 years). The study have not included patients with symptomatic hypertension, diabetes mellitus, coronary heart disease. The 24-h mean, daytime mean, night-time mean systolic and diastolic BP (24-h SBPm, 24-h dBPm, dSBPm, dDBPm, $\mathrm{nSBPm}, \mathrm{nDBPm}$ ), the level of night-time SBP, DBP dipping (ndSBP, ndDBP), index of time of 24-h, day, night systolic and diastolic BP (TI 24-h SBP, TI 24-h DBP, TI dSBP, TI dDBP, TI $\mathrm{nSBP}$, TI nDBP), magnitude and speed of morning increase of systolic and diastolic BP (MMI SBP, MMI DBP, SMI SBP, SMI DBP) have been defined. With echocardiography-study the end diastolic and systolic size (EDS, ESS), the volumes (EDV, ESV) of the left ventricle (LV), the size of left atrium (LA), the right ventricle have been defined with subsequent indexation of indices to the body area, the thickness of the posterior wall of the LV (LVPWTd), of the interventricular septum (IVSTd) in diastole, fraction of ejection (EF), relative thickness of the myocardium, index of mass of myocardium of LV (LVMMi). To characterise the diastolic function of LV (LVDF) the maximum speed of early (E) and late (A) diastolic filling has been measured. The E/A (diastolic index) has been defined, $\mathrm{Te}, \mathrm{Ta}$ (time of early and late diastolic filling), $\mathrm{Ei}, \mathrm{Ai}$ (area under the curve of early and late diastolic filling), \% $\Delta \mathrm{A}$ (percentage of LA input into the LV filling), $\mathrm{Ta} / \mathrm{Te}$ (ratio of time of late versus time of early diastolic filling). The function of the endothelium of the vessels was determined by the method of Doppler examination of right shoulder artery using the Celermajer-Sorensen technique (endothelium-dependent vasodilatation - EDVD): the initial diameter of the artery was measured as well as the after reaction of hyperemia in 90 seconds. For determination of endothelial-independent vasodilatation (EIVD), the diameter of the artery was measured in 5 minutes after taking of $0,5 \mathrm{mg}$ of nitroglycerine sublingually. The increase in diameter of this artery for more than $10 \%$ after the reaction of hyperemia after 90 seconds and more than $20 \%$ after 5 minutes after taking of nitroglycerin was considered normal. The intima-media thickness (IMT) of the same artery was also measured.

Initial treatment began with three-component therapy, which included the beta-blocker (BB) bisoprolol-hemifumarate at a dose of $5 \mathrm{mg}$ per day, an angiotensin-converting enzyme inhibitor (ACEi) lysinopril-dihydrate in a dose of
$10 \mathrm{mg}$ per day, a diuretic hydrochlorothiazide at a dose of $12.5 \mathrm{mg}$ per day. The duration of the initial treatment ranged from 5 to 10 days. The evaluation of the effectiveness of the prescribed therapy was carried out every 5-10 days. With insufficient antihypertensive effect of starting therapy, the dose of lisinopril was increased to $20 \mathrm{mg}$ per day. If it was not possible to reach the target level for the above-mentioned three-component therapy, a calcium channel blocker (CCB) amlodipine in a dose of $5 \mathrm{mg}$ per day was added to it. With its insufficient effectiveness, the dose of amlodipine was increased to $10 \mathrm{mg}$ per day. Subsequently, after reaching the target BP level, if necessary, the dose of amlodipine was reduced from 10 to $5 \mathrm{mg}$ per day. Evaluation of effectiveness of the prescribed treatment was carried out according to clinical data and data of ABPM after 3 months. With clinical benefit and the consent of the patient for further participation in the study, the prescribed therapy was continued for up to 6 months.

\section{RESULTS}

During ABPM, 2 types of daily BP profile have been identified: "dipper" (67 patients) and "non-dipper" (43 patients). According to the type of geometric models of LV, all patients were divided into 2 groups: a concentric hypertrophy of LV (CHLV) - 95 patients and an eccentric hypertrophy of LV (EHLV) - 15 patients. In the group of patients with CHLVB 58 patients had a "dipper" daily profile of BP, 37 - "non-dipper", in the group of patients with EHLV -9 and 6 respectively.

In patients with CHLV, the three-component therapy was effective in 49 "dipper" patients and only in 3 "non-dipper" patients; respectively 9 and 34 patients with these profiles needed an additional amlodipine treatment. In patients with EHLV, the three-component therapy was effective in 5 "dipper" patients. Amlodipine was added to 4 patients for the "dipper" and to all "non-dipper" patients.

In patients with CHLV and "dipper" profile and effective response to the three-component therapy, a significant decrease in BP has been noted after 3 months, and subsequent stabilisation after 6 months (24-h SBPm from 147,88 $\pm 2,07$ to $130,53 \pm 2,19$ and $129,37 \pm 1,89 \mathrm{~mm} \mathrm{Hg}, 24-\mathrm{h} \mathrm{dBPm}$ from $92,10 \pm 1,83$ to $80,29 \pm 2,39$ and $79,51 \pm 2,21 \mathrm{~mm} \mathrm{Hg}$, dSBPm from $154,67 \pm 1,86$ to $134,51 \pm 1,80$ and $133,55 \pm 1,34 \mathrm{~mm} \mathrm{Hg}$, dDBPm from $96,04 \pm 1,74$ to $82,63 \pm 1,83$ and $82,06 \pm 1,71$ $\mathrm{mm} \mathrm{Hg}, \mathrm{nSBPm}$ from $132,69 \pm 1,95$ to $115,65 \pm 1,76$ and $114,20 \pm 1,38 \mathrm{~mm} \mathrm{Hg}, \mathrm{nDBPm}$ from $82,24 \pm 1,63$ to $70,57 \pm 1,73$ and $70,00 \pm 1,59 \mathrm{~mm} \mathrm{Hg})(\mathrm{p}<0,001)$. Accordingly, after 3 months significant decrease of indicators of pressure on target organs was noted, namely, 24 -h (from $67,73 \pm 2,33$ to $31,31 \pm 1,99 \%$, from $48,90 \pm 2,15$ to $24,00 \pm 1,53$ $\%$ ), day (from $69,61 \pm 2,19$ to $33,84 \pm 1,28 \%$, from $52,69 \pm 2,14$ to $26,10 \pm 1,39 \%$ ), night (from $62,04 \pm 2,43$ to $32,69 \pm 1,40$, from $42,16 \pm 1,93$ to $22,96 \pm 1,68 \%)(\mathrm{p}<0,001)$ time indexes of SBP, DBP with subsequent stabilization of these indicators in 6 months $(\mathrm{p}<0.001)$.

In patients with CHLV and "non-dipper" profile and effective response to the three-component therapy, a 
similar dynamics of these indicators has been noted: decrease of 24 -h SBPm from $159,33 \pm 0,58$ to $132,00 \pm 1,73$ and $130,67 \pm 0,58 \mathrm{~mm} \mathrm{Hg}, 24-\mathrm{h} \mathrm{dBPm}$ from $97,33 \pm 1,15$ to $82,67 \pm 0,58$ and $82,33 \pm 1,15 \mathrm{~mm} \mathrm{Hg}$, dSBPm from $162,33 \pm 0,58$ to $134,67 \pm 1,53$ and $134,00 \pm 1,00 \mathrm{~mm} \mathrm{Hg}$, dDBPm from $99,67 \pm 2,08$ to $83,67 \pm 0,58$ and $83,00 \pm 0,00 \mathrm{~mm} \mathrm{Hg}$, nSBPm from $151,67 \pm 0,58$ to $120,33 \pm 1,15$ and $117,33 \pm 0,58$ $\mathrm{mm} \mathrm{Hg}, \mathrm{nDBPm}$ from $92,00 \pm 2,00$ to $74,00 \pm 1,00$ and $71,67 \pm 0,58 \mathrm{~mm} \mathrm{Hg})(\mathrm{p}<0,05)$. This contributed to a significant decrease in 3 months of the corresponding 24 -h (from $81,33 \pm 1,53$ to $33,00 \pm 1,00 \%$, from $67,00 \pm 2,65$ to $25,33 \pm 1,15 \%$ ), day (from $82,33 \pm 1,15$ to $35,33 \pm 1,15 \%$, from $69,69 \pm 2,14$ to $27,67 \pm 1,53 \%$ ), night (from $80,67 \pm 1,15$ to $32,67 \pm 0,58$, from $69,67 \pm 3,06$ to $24,33 \pm 1,15 \%)(p<0,01)$ time indexes of SBP and DBP with the stabilization of these indicators in 6 months.

In the course of study of a group of patients with EHLV and the four-component therapy up to 3 months, the patients with "dipper" daily profile have left and only "non-dipper" patients have remained. In patients with EGLV and "dipper" profile at the background of three-component therapy, there was a significant stable decrease in the level of SBP and DBP after both 3 and 6 months (24-h SBPm from $148,40 \pm 3,44$ to $131,00 \pm 2,92$ and $130,50 \pm 1,73$ $\mathrm{mm} \mathrm{Hg}, 24-\mathrm{h} \mathrm{dBPm}$ from $91,80 \pm 1,79$ to $78,60 \pm 0,55$ and $77,75 \pm 0,96 \mathrm{~mm} \mathrm{Hg}, \mathrm{dSBPm}$ from $154,40 \pm 2,88$ to $134,80 \pm 1,10$ and $134,00 \pm 0,82 \mathrm{~mm} \mathrm{Hg}, \mathrm{dDBPm}$ from $96,00 \pm 1,22$ to $83,00 \pm 1,87$ and $83,00 \pm 2,16 \mathrm{~mm} \mathrm{Hg}, \mathrm{nSBPm}$ from $135,00 \pm 7,42$ to $116,40 \pm 2,19$ and $115,25 \pm 1,89 \mathrm{~mm} \mathrm{Hg}$, nDBPm from $83,40 \pm 4,28$ to $71,20 \pm 2,28$ and $71,25 \pm 1,89$ $\mathrm{mm} \mathrm{Hg},(\mathrm{p}<0,05))$. This was accompanied by a significant decrease in 3 months of the 24 -h (from $73,60 \pm 5,68$ to $33,17 \pm 1,17 \%$, from $57,80 \pm 3,74$ to $24,33 \pm 1,03 \%$ ), day (from $75,50 \pm 6,22$ to $35,33 \pm 1,03 \%$, from $60,10 \pm 8,12$ to $35,33 \pm 1,03$ $\%$ ), night (from $60,10 \pm 8,12$ to $27,00 \pm 0,63$, from $70,20 \pm 3,38$ to $34,00 \pm 1,26 \%)(p<0,05)$ time indexes of SBP and DBP with stabilization of these indicators in 6 months.

In the group of patients with CHLV and "dipper" profile whith ineffective responce to the three-component therapy, the prescription of amlodipine has allowed to lower BP to the target level, which was accompanied by a significant decrease in BP after both 3 and 6 months (24-h SBPm from $149,78 \pm 1,39$ to $132,22 \pm 3,49$ and $130,33 \pm 2,18$ $\mathrm{mm} \mathrm{Hg}, 24-\mathrm{h}$ dBPm from $93,33 \pm 1,50$ to $79,22 \pm 2,91$ and $78,78 \pm 2,33 \mathrm{~mm} \mathrm{Hg}$, dSBPm from $156,22 \pm 0,97$ to $135,33 \pm 1,32$ and $134,00 \pm 1,58 \mathrm{~mm} \mathrm{Hg}$, dDBPm from $97,22 \pm 1,99$ to $82,44 \pm 2,19$ and $82,00 \pm 2,35 \mathrm{~mm} \mathrm{Hg}, \mathrm{nSBPm}$ from $134,89 \pm 1,27$ to $116,44 \pm 1,67$ and $115,33 \pm 1,12 \mathrm{~mm} \mathrm{Hg}$, nDBPm from $83,33 \pm 1,80$ to $70,56 \pm 2,01$ and $70,22 \pm 1,92$ $\mathrm{mm} \mathrm{Hg})(\mathrm{p}<0,01)$. Accordingly, after 3 months. significant decrease of indicators of pressure on the target organs has been noted, namely, 24 -h (from $69,89 \pm 1,62$ to $31,56 \pm 1,33$ $\%$, from $50,44 \pm 1,67$ to $23,67 \pm 1,50 \%$ ), day (from $71,56 \pm 1,01$ to $33,56 \pm 1,33 \%$, from $53,44 \pm 1,24$ to $25,89 \pm 1,69 \%$ ), night (from $62,89 \pm 0,93$ to $33,56 \pm 1,88$, from $44,22 \pm 1,86$ to $22,56 \pm 1,94 \%)(p<0,001)$ time indexes of SBP and DBP with stabilization of these indicators in 6 months $(\mathrm{p}<0,001)$.

The group of patients with CHLV and "non-dipper" profile was marked with similar dynamics: decrease of 24-h SBPm from $160,24 \pm 1,72$ to $133,27 \pm 2,35$ and $131,24 \pm 1,57$ $\mathrm{mm} \mathrm{Hg}, 24-\mathrm{h} \mathrm{dBPm}$ from $98,68 \pm 1,61$ to $81,60 \pm 1,98$ and $80,62 \pm 1,78 \mathrm{~mm} \mathrm{Hg}$, dSBPm from $163,65 \pm 1,41$ to $135,47 \pm 1,93$ and $134,10 \pm 0,98 \mathrm{~mm} \mathrm{Hg}$, dDBPm from $101,76 \pm 1,72$ to $83,70 \pm 1,73$ and $82,93 \pm 1,28 \mathrm{~mm} \mathrm{Hg}, \mathrm{nSBPm}$ from $152,56 \pm 1,83$ to $120,97 \pm 1,59$ and $117,10 \pm 0,90 \mathrm{~mm} \mathrm{Hg}$, nDBPm from $94,09 \pm 1,60$ to $73,73 \pm 1,62$ and $71,86 \pm 1,16$ $\mathrm{mm} \mathrm{Hg})(\mathrm{p}<0,001)$. This contributed to a significant decrease in 3 months of corresponding 24 -h (from $82,32 \pm 2,21$ to $33,57 \pm 1,28 \%$, from $69,21 \pm 1,93$ to $24,80 \pm 1,30 \%$ ), day (from $83,41 \pm 1,44$ to $35,50 \pm 1,38 \%$, from $71,00 \pm 1,78$ to $27,23 \pm 1,30 \%$ ), night (from $82,65 \pm 2,03$ to $33,80 \pm 1,27$, from $71,76 \pm 2,02$ to $23,67 \pm 1,60 \%)(\mathrm{p}<0,001)$ time indexes of SBP and DBP with stabilization of these indicators in 6 months $(\mathrm{p}<0,001)$.

In patients with EHLV at the background of four-component therapy, a steady decrease in the level of SAP and DAP after both 3 and 6 month has been observed (24-h SBPm from $151,70 \pm 3,65$ to $132,17 \pm 2,86$ and $130,50 \pm 2,07$ $\mathrm{mm} \mathrm{Hg}, 24$-h dBPm from $93,70 \pm 1,77$ to $81,83 \pm 1,47$ and $81,33 \pm 1,75 \mathrm{~mm} \mathrm{Hg}$, dSBPm from $157,00 \pm 2,91$ to $135,83 \pm 1,47$ and $133,83 \pm 0,98 \mathrm{~mm} \mathrm{Hg}$, dDBPm from $97,10 \pm 1,85$ to $83,33 \pm 0,82$ and $83,17 \pm 1,17 \mathrm{~mm} \mathrm{Hg}, \mathrm{nSBPm}$ from $140,40 \pm 3,04$ to $118,50 \pm 2,95$ and $116,17 \pm 1,47 \mathrm{~mm} \mathrm{Hg}$, nDBPm from $86,50 \pm 4,47$ to $72,33 \pm 1,63$ and $72,00 \pm 1,47$ $\mathrm{mm} \mathrm{Hg},(\mathrm{p}<0,05)$. This contributed to a significant decrease in 3 months of corresponding $24-\mathrm{h}$ (from $68,80 \pm 4,71$ to $31,60 \pm 1,67 \%$, from $52,60 \pm 4,30$ to $23,40 \pm 0,89 \%$ ), day (from $71,20 \pm 5,54$ to $33,80 \pm 1,30 \%$, from $54,80 \pm 6,91$ to $26,00 \pm 0,73$ $\%$ ), night (from $64,00 \pm 7,92$ to $32,20 \pm 1,92$, from $47,00 \pm 8,79$ to $22,60 \pm 0,55 \%)(\mathrm{p}<0,05)$ time indexes of SBP and DBP with stabilization of these indicators in 6 months.

It has been noted that in patients who received amlodipine, the average $\mathrm{BP}$ was higher than in patients with initially effective three-component therapy. Addition of amlodipine has allowed not only to lower the AP to the target level, but also to stabilise it throughout the observation period and to normalize the BP profile in the group of patients with its insufficient night decrease. Having compared both treatments in 6 months, a slightly higher antihypertensive effect has been observed at the background of four-component therapy in all groups of patients, since the percentage of lowering of BP average parameters compared with baseline data was slightly higher in patients receiving amlodipine. However, this difference was insignificant. The results of other studies confirm the fact that most patients require namely the combination of antihypertensive treatment. Therapy with using of ACEi, CCB, BB, diuretic for 6 months positively affects the parameters of brachial $\mathrm{BP}$, reduces the degree of LVH and displays of DD [7, 8].

In evaluating of parameters of echocardiography in patients with CHLV and certain types of daily profile of BP at the background of three-component therapy, the significant improvement of structural-geometric parameters in both groups of patients was noted only in 6 months. However, more pronounced changes were observed in patients with "dipper" group: decrease of EDSi from 2,84 $\pm 0,06$ 
to $2,59 \pm 0,02 \mathrm{~cm} / \mathrm{m}^{2}$, ESSi from $1,90 \pm 0,04$ to $1,74 \pm 0,01$ $\mathrm{cm} / \mathrm{m}^{2}$, EDVi from $69,99 \pm 3,03$ to $56,56 \pm 1,76 \mathrm{ml} / \mathrm{m}^{2}$, LVMMi from $109,62 \pm 2,73$ to $92,39 \pm 1,89 \mathrm{~g} / \mathrm{m}^{2}$ ( $\left.\mathrm{p}<0,001\right)$, LAi from $2,17 \pm 0,03$ to $2,02 \pm 0,03 \mathrm{~cm} / \mathrm{m}^{2}$ ( $\left.\mathrm{p}<0,01\right)$, ESVi from $27,29 \pm 1,91$ to $22,05 \pm 0,86 \mathrm{ml} / \mathrm{m}^{2}$ ( $\left.\mathrm{p}<0,01\right)$, LVPWTd from $1,25 \pm 0,02$ to $1,18 \pm 0,02 \mathrm{~cm}(\mathrm{p}<0,01)$, IVSTd from $1,29 \pm 0,02$ to $1,20 \pm 0,02 \mathrm{~cm}(\mathrm{p}<0,01)$. In "non-dipper" group only the following parameters have changed: LAi from $2,20 \pm 0,02$ to $2,06 \pm 0,02 \mathrm{~cm} / \mathrm{m}^{2}$, LVMMi from $112,93 \pm 0,91$ to $97,43 \pm 1,62$ $\mathrm{g} / \mathrm{m}^{2}$, ESVi from $29,87 \pm 0,99$ to $23,79 \pm 0,86 \mathrm{ml} / \mathrm{m}^{2}$, IVSTd from $1,35 \pm 0,02$ to $1,25 \pm 0,01 \mathrm{~cm}(\mathrm{p}<0,05)$. The evaluation of the parameters of DF has showed that in both groups of patients under the influence of three-component therapy a tendency to its improvement has been observed in 6 months, but this difference was insignificant.

Unlike the three-component, the four-component therapy contributed after 3 months to a minimal significant decrease of ESSi, ESVi, LVMMi $(\mathrm{p}<0,05)$ in the group of patients with CHLV and "dipper" profile and LAi, ESVi ( $p<0.05)$ in "non-dipper" group. In the evaluation of structural and geometric indices after 6 months, it has been noted that in both groups, the additional use of amlodipine contributed to their further improvement, moreover, more significant than at the background of three-component therapy. This was accompanied by a decrease of EDSi from $2,83 \pm 0,05$ to $2,60 \pm 0,02 \mathrm{~cm} / \mathrm{m}^{2}$, LAi from $2,24 \pm 0,03$ to $2,05 \pm 0,03 \mathrm{~cm} / \mathrm{m}^{2}$, LVPWTd from $1,28 \pm 0,02$ to $1,20 \pm 0,01 \mathrm{~cm}(\mathrm{p}<0,01)$, IVSTd from $1,33 \pm 0,02$ to $1,22 \pm 0,01 \mathrm{~cm}(\mathrm{p}<0,01)$, ESSi from $1,94 \pm 0,03$ to $1,75 \pm 0,01$ $\mathrm{cm} / \mathrm{m}^{2}$, EDVi from $71,77 \pm 1,03$ to $58,80 \pm 0,90 \mathrm{ml} / \mathrm{m}^{2}$, ESVi from $29,44 \pm 1,03$ to $22,95 \pm 0,64 \mathrm{ml} / \mathrm{m}^{2}$, LVMMi from $112,42 \pm 1,0$ to $94,44 \pm 1,21 \mathrm{~g} / \mathrm{m}^{2}(\mathrm{p}<0,001)$. In "non-dipper" group the decrease of EDSi from 2,80 $\pm 0,06$ to 2,62 $\pm 0,02$ $\mathrm{cm} / \mathrm{m}^{2}$, LVPWTd from $1,30 \pm 0,02$ to $1,22 \pm 0,01 \mathrm{~cm}(\mathrm{p}<0,01)$, IVSTd from $1,37 \pm 0,05$ to $1,25 \pm 0,02 \mathrm{~cm}(\mathrm{p}<0,05)$, LAi from $2,26 \pm 0,04$ to $2,06 \pm 0,02 \mathrm{~cm} / \mathrm{m}^{2}$, ESSi from $1,95 \pm 0,03$ to $1,76 \pm 0,01 \mathrm{~cm} / \mathrm{m}^{2}$, EDVi from $71,68 \pm 1,32$ to $61,51 \pm 2,30 \mathrm{ml} /$ $\mathrm{m}^{2}$, ESVi from $30,51 \pm 1,00$ to $23,80 \pm 0,90 \mathrm{ml} / \mathrm{m}^{2}$, LVMMi from $114,66 \pm 1,82$ to $97,73 \pm 1,56 \mathrm{~g} / \mathrm{m} 2(\mathrm{p}<0,001)$ has been observed.

It has been noted that addition of amlodipine has not only allowed to lower the AP to the target level, but also has contributed to more pronounced decrease in the degree of HLV, rigidity of the myocardium, and more significant improvement in the active relaxation of the lungs and intracardiac hemodynamics. Having evaluated functional indicators, it has been found out that unlike the three-component, the four-component therapy in both groups contributed to their improvement after 3 months with the following positive dynamics in 6 months. In "dipper" group the increase in the ratio $\mathrm{E} / \mathrm{A}$ from $0,81 \pm 0,04$ to $1,07 \pm 0,04(\mathrm{p}<0,01)$ has been noted, the decrease of $\% \Delta \mathrm{A}$ from $40,00 \pm 1,06$ to $35,21 \pm 1,71 \%(\mathrm{p}<0,05)$ after 3 months. After 6 months E/A increased to $1,12 \pm 0,03(\mathrm{p}<0,001)$, $\% \Delta \mathrm{A}$ decreased to $35,41 \pm 0,83 \%$. Also the decrease of Tdec from $167,22 \pm 6,67$ to $146,67 \pm 5,59 \mathrm{~ms}(\mathrm{p}<0,001)$. In "non-dipper" group the correlation of E/A after 3 months decreased from $0,78 \pm 0,03$ to $1,01 \pm 0,05$ and to $1,06 \pm 0,04$ after 6 months $(\mathrm{p}<0,001), \% \Delta \mathrm{A}$ decreased from $42,07 \pm 1,32$ to $36,97 \pm 1,74 \%(\mathrm{p}<0,05)$ and to $36,77 \pm 1,06 \%(\mathrm{p}<0,01)$, Tdec from $175,88 \pm 7,01$ to $156,17 \pm 4,86(\mathrm{p}<0,05)$ and to $148,62 \pm 3,0 \mathrm{~ms}(\mathrm{p}<0,01)$ respectively.

The evaluation of echocardiographic-study has showed that in patients with EHLV and certain types of daily profile, both treatment schemes have not caused after 3 months significant improvement of structural and geometric indicators. However, after 6 months in the group of patients with effective three-component therapy a significant decrease of EDSi from $2,86 \pm 0,04$ to $2,64 \pm 0,03 \mathrm{~cm} / \mathrm{m}^{2}(\mathrm{p}<0,05)$, ESSi from $2,06 \pm 0,04$ to $1,81 \pm 0,02 \mathrm{~cm} / \mathrm{m}^{2}(\mathrm{p}<0,05)$, EDVi from $82,25 \pm 2,28$ to $68,28 \pm 1,19 \mathrm{ml} / \mathrm{m}^{2}(\mathrm{p}<0,001)$, ESVi from $38,37 \pm 1,89$ to $28,14 \pm 0,37 \mathrm{ml} / \mathrm{m}^{2}(\mathrm{p}<0,05)$, LVMMi from $106,94 \pm 2,74$ to $93,68 \pm 1,10 \mathrm{~g} / \mathrm{m}^{2}(\mathrm{p}<0,05)$ has been observed. The same dynamics in 6 months has been observed in the group of patients with the four-component therapy: decrease of EDSi from $2,93 \pm 0,06$ to $2,63 \pm 0,04$ $\mathrm{cm} / \mathrm{m}^{2}(\mathrm{p}<0,05)$, ESSi from $2,11 \pm 0,05$ to $1,81 \pm 0,02 \mathrm{~cm} / \mathrm{m}^{2}$ $(\mathrm{p}<0,01)$, EDVi from $83,88 \pm 2,01$ to $65,98 \pm 1,64 \mathrm{ml} / \mathrm{m}^{2}$, ESVi from $39,14 \pm 2,64$ to $27,46 \pm 1,04 \mathrm{ml} / \mathrm{m}^{2}$ ( $\left.\mathrm{p}<0,05\right), \mathrm{LVMMi}$ from $106,74 \pm 1,42$ to $93,13 \pm 1,10 \mathrm{~g} / \mathrm{m}^{2}(\mathrm{p}<0,01)$.

In the assessment of LVDF, its improvement has been noted in both groups, which was characterised by an increase in E/A ratio from $0,81 \pm 0,02$ to $1,02 \pm 0,01 \mathrm{~m} / \mathrm{s}$ $(\mathrm{p}<0.01)$ in 3 months and up to $1,05 \pm 0.00 \mathrm{~m} / \mathrm{s}(\mathrm{p}<0.001)$ in 6 months in "dipper" patients with under the influence of the three-component therapy and from $0,79 \pm 0,02$ to $1,02 \pm 0,01 \mathrm{~m} / \mathrm{s}(\mathrm{p}<0.001)$ in 3 months and to $1,06 \pm 0,01$ $\mathrm{m} / \mathrm{s}(\mathrm{p}<0,001)$ in 6 months in "non-dipper" patients under the influence of the four-component therapy.

In numerous studies, it has been shown that a decrease in LVMMi is associated with an improvement of DF, a decrease of LA size, and of vascular stiffness. This is essential because it is important not only to prescribe drugs that lower BP, but also to have a positive effect on myocardial hypertrophy and elastic properties of blood vessels. The combination of ACEi and CCB is exactly the same [9].

In assessing the dynamics of structural and functional parameters of vessels, the following results have been obtained. In patients with CHLV with "dipper" profile the significant reduction of the processes of pathological remodelling of the vascular wall was noted after 3 months, which was displayed by the decrease of the IMT from 0,45 $\pm 0,02$ to $0,39 \pm 0,01 \mathrm{~mm}(-13,33 \%)(\mathrm{p}<0,01)$ and to 0,34 $\pm 0,01 \mathrm{~mm}(-24,44 \%)$ after 6 months. Having analyzed the function of the endothelium, it has been noted that 3 months treatment with bisoprolol, lisinopril, hydrochlorothiazide contributed to the increase in the growth of the diameter of the brachial artery after the reaction of hyperemia from $10,26 \pm 0,18 \%$ to $21,36 \pm 0,34 \%(\mathrm{p}<0.001)$, followed by its increase to $23,81 \pm 0,22 \%$ in 6 months ( $p<0.001$ ). Having evaluated EIVD after 3 months, the increase in the growth of the diameter of the brachial artery from 19,39 $\pm 0,23 \%$ to $28,82 \pm 0,38 \%(p<0.001)$ has been noted with the subsequent improvement of this indicator in 6 months (increase in growth to $30,04 \pm 0,30 \%(\mathrm{p}<0.001)$ ). 
In patients with CHLV and "non-dipper" profile the three-component therapy either after 3 months, or after 6 months have not contributed to a significant reduction of the IMT (from $0,57 \pm 0,09$ to $0,47 \pm 0,03(-17,54 \%$ ) and to 0,40 $\pm 0,00 \mathrm{~mm}(-29,82 \%)$. However, in this group of patients, the minimal significant improvement of the endothelium function has been observed, which was characterised by an increase in the growth of the diameter of the brachial artery after the reaction of hyperemia after 3 months from $8,19 \pm 0,17 \%$ to $18,01 \pm 0,78 \%$ and to $21,59 \pm 1,02 \%$ after 6 months $(\mathrm{p}<0.05)$, and after the test with nitroglycerin from $18,08 \pm 0,53 \%$ to $24,14 \pm 1,7 \%$ and $27,08 \pm 0,93 \%$ respectively $(\mathrm{p}<0.05)$.

Adding of amlodipine to patients with CHLV with "dipper" profile has allowed to reduce of the IMT in this group after 3 months from $0,49 \pm 0,03$ to $0,41 \pm 0,01 \mathrm{~mm}(-16,33 \%)$ $(\mathrm{p}<0,05)$ and to $0,39 \pm 0,01 \mathrm{~mm}(-20,41 \%)$ in 6 months $(\mathrm{p}<0.05)$. EIVD has improved from $10,10 \pm 0,30 \%$ to 19,11 $\pm 1,94 \%(\mathrm{p}<0.001)$ after 3 months and to $23,18 \pm 0,0,59 \%$ after 6 months $(\mathrm{p}<0,001)$. Unlike the three-component therapy, the four-component therapy in patients with CGLV and "non-dipper" profile has proved to be more effective, since under its influence already after 3 months a significant reduction in the thickness of CIM from $0,54 \pm 0,02$ to 0,46 $\pm 0,01 \mathrm{~mm}(-14,81 \%)(\mathrm{p}<0,01)$ and after 6 months to 0.41 $\pm 0.01(-24.07 \%)(p<0.001)$ has been onserved. The same positive dynamics has been noted in the evaluation of endothelial function, which was followed with improvement in 3 and 6 months both in EDVD (increase in the growth of the diameter of the brachial artery from $8,13 \pm 0,19 \%$ to $18,99 \pm 0,35 \%$ and up to $21,92 \pm 0.33 \%(\mathrm{p}<0.001)$, as well as in EIVD (increase in the growth from $16,87 \pm 0,17 \%$ to $26,43 \pm 0,27$ and to $27,73 \pm 0.21 \%(\mathrm{p}<0.001)$ ).

A similar tendency has been observed in patients with EHLV. Thus, in "dipper" patients the three-component therapy has contributed to a significant improvement of both EDVD (increase in the growth of the diameter of the brachial artery from $9,27 \pm 0,6 \%$ to $19,73 \pm 0.33 \%(p<0.01)$ in 3 months and up to $22,03 \pm 0,24 \%$ in 6 months $(p<0,01)$ ) and in the EIVD (increase in the growth from $17,08 \pm 0,59 \%$ to $24,10 \pm 0,55 \%(\mathrm{p}<0,01)$ and up to $26,29 \pm 0,37 \%(\mathrm{p}<0,01)$ respectively). At the background of the four-component therapy in "non-dipper" patients the improvement of EDVD has been noted from $9,47 \pm 0,19 \%$ to $19,83 \pm 0,63 \%$ after 3 months and up to $22,30 \pm 0,58 \%$ in 6 months ( $\mathrm{p}<0,001)$, EIVD from $17,14 \pm 0,57 \%$ to $24,32 \pm 0,60 \%(\mathrm{p}<0,001)$ and up to $26,82 \pm 0,24 \%(\mathrm{p}<0.001)$ respectively. After 6 months the reduction of the IMT in both groups has been observed (under the influence of the three-component therapy from $0,46 \pm 0,02$ to $0,40 \pm 0,00 \mathrm{~mm}(-13,04 \%)$, at the background of the four-component therapy from $0,45 \pm 0,02$ to 0,37 $\pm 0,02 \mathrm{~mm}(-17.78 \%)$, but this difference was unreliable. According to numerous studies, the violation of the elastic properties of the arteries, regardless of the level of $\mathrm{BP}$, is associated with LVH, the IMT, LVDD. ACEi and CCB positively effect on the stiffness of the myocardium and arteries. The extent of the effect of ACEi on the arteries may be partially genetically determined.

\section{DISCUSSION}

Analysing the structural and functional parameters of the heart and blood vessels, it has been established that higher levels of BP and longer duration pressure on the target organs in "non-dipper" patients contributed to the development of a more pronounced $\mathrm{LVH}$, thickening of IMT, increased rigidity of the myocardium and vessels, violation of their relaxation. Subsequently, this has led to more significant violations of LVDF and EF of vessels.

Evaluating the effectiveness of combined antihypertensive treatment, it has been found that three-component therapy was initially effective in patients with lower BP. An additional use of amlodipine to lower BP to the target levels has appeared to be necessary for the majority "non-dipper" patients and the minority of "dipper" patients. Both treatment schemes contributed to a significant decrease in BP after 3 months with subsequent stabilisation in 6 months. At the background of the three-component therapy after 6 months the reduction of displays of pathological remodelling, including LVH only in "dipper" patients has been noted. However, in both groups of patients, this treatment have not contributed to a significant improvement in DF even in 6 months. The additional use of amlodipine has not only allowed to lower the BP to the target level, but also significantly to reduced after 6 months the displays of pathological remodelling and DD in patients with both types of 24-h profile of BP.

It is known that ACEi improves the function of the endothelium by preventing the implementation of mitotic and proliferative effects of AT II, blocking the synthesis of peroxydanion, which inactivates NO, increases the formation of NO, slows the degradation of bradykinin, reduces the synthesis of collagen and the development of fibrosis. CCB limits the vasoconstrictive effect of AT II, endothelin- 1 by reducing the intracellular calcium pool, possess antioxidant properties, stimulate the synthesis of NO. Thus, CCB provides additional organoprotective action to the ACEi. According to the literature, including the research of HAMLET, ELVERA, ROZALIA, the combination of lisinopril, amlodipine and lisinopril, amlodipine, hydrochlorothiazide has broad evidence base of clinical efficacy and safety, possess long proven antihypertensive effect, synergy component, allows to monitor the morning rise of $\mathrm{BP}$, has confirmed organoprotective properties, ability to reduce the level of $\mathrm{LVH}$, manifestations of DD, proteinuria, $\mathrm{ED}$, is well tolerated by patients. It has been proved that this combination helps to reduce the risk of development of the primary combined endpoint of "death and cardiovascular complications" in patients with high-risk $[10,11]$.

Thus, the obtained by us results show the high efficiency of combined antihypertensive therapy, which includes ACEi, BB, diuretic, CCB. Both treatment schemes not only have had the pronounced antihypertensive effect, but also have reduced the displays of pathological remodelling of the CVS, which further reduces the risk of complications and mortality.

\section{CONCLUSIONS}

In patients with essential hypertension of the II-nd stage with hypertensive heart, HHF) of the 0 -I stage with the daily "non-dipper" profile higher mean 24-h, day, and night SBP and DBP are regis- 
tered, as well as the corresponding time indices, speed of morning increase of SBP and DBP than in patients with daily "dipper" profile, which leads to more pronounced structural-geometric and functional changes in the heart and blood vessels. Prolonged, during 6 months, combined antihypertensive therapy reduces the displays of disadaptive remodelling of the cardiovascular system, diastolic and endothelial dysfunction. With the lack of efficacy of the three-component antihypertensive therapy, which includes BB bisoprolol, ACEi lisinopril, diuretic hydrochlorothiazide, the addition of $\mathrm{CCB}$ amlodipine allows to reach the target level of $\mathrm{BP}$, reduces the pressure burden on the target organs and reduces the risk of cardiovascular complications and mortality.

\section{REFERENCES}

1. Amosova KM, Rudenko YuV. Klinichne znachennia variabelnosti domashnoho arterialnoho tysku na pochatkovomu etapi likuvannia khvorykh iz neuskladnenoiu arterialnoiu hipertenziiu [The reasons for the ineffectiveness of antihypertensive therapy in patients with uncomplicated hypertension in real life setting]. Ukrainskyi terapevtychnyi zhurnal. 2016;(2):5-13. (In Ukrainian).

2. Lutay MI. Efektyvnist kombinovanoi terapii arterialnoi hipertenzii v Ukraini: rezultaty bahatotsentrovoho doslidzhennia TRIUMF [Efficiency of the combined treatment of arterial hypertension in Ukraine: results of the TRIUMF multicenter study]. Ukrainskyi kardiolohichnyi zhurnal. 2016;(4):17-28. (In Ukrainian).

3. Swishchenko YeP,MishchenkoLA. Kliniko-demohrafichni kharakterystyky patsiientiv $z$ upershe vyiavlenoiu arterialnoiu hipertenziieiu: rezultaty doslidzhennia START [Clinical and demographic characteristics of the patients with arterial hypertension: results of START study]. Ukrainskyi kardiolohichnyi zhurnal. 2017;(6):14-22. (In Ukrainian).

4. Williams B, Mancia G, Spiering W et al. ESC/ESH Guidelines for the management of arterial hypertension. European Heart Journal. 2018; 39(33): 3021-3104.

5. Gorobets NM. Rol biolohichno aktyvnoi spoluky oksydu azotu v rozvytku arterialnoi hipertenzii ta yii uskladnen [The role of nitric oxide biologically active compound in the development of arterial hypertension and its complications]. Ukrainskyi terapevtychnyizhurnal. 2016;(2):81-85. (In Ukrainian).

6. Lutay MI, Lysenko AF. Likuvannia arterialnoi hipertenzii fiksovanoiu kombinatsiieiu inhibitora anhiotenzynperetvoriuiuchoho fermentu, blokatora kaltsiievykh kanaliv i tiazydopodibnoho diuretyka. Rezultaty ukrainskoho bahatotsentrovoho doslidzhenniaTRIUMF-2 [Treatment ofarterial hypertension with a fixed combination of ACEinhibitor, calcium channel blocker and thiazide-type diuretic. The results of the Ukrainian multicenter study TRIUMF-2].Ukrainskyikardiolohichnyizhurnal.2017;(4):16-28. (InUkrainian).

7. Sydorova LL. Trekhkomponentnaia skhema lechenyia bolnbkhs arteryalnoi hypertenzyei s dokazannoi əffektyvnostiu y bezopasnostiu [Threecomponent scheme of treatment of patients with arterial hypertension with proven efficacy and safety]. Terapiia. 2017;(10):14-18.( In Russian).

8. Amosova KM, Lazareva KP, Lazarev PO. et al. Vplyv kontroliu arterialnoho tysku za dopomohoiu blokatora kaltsiievykh kanaliv i riznykh inhibitoriv renin-anhiotenzynovoi systemy na pokaznyky tsentralnoi hemodynamiky y zhorstkosti arterii u patsiientiv z neuskladnenoiu arterialnoiu hipertenziieiu: rezultaty shestymisiachnoho sposterezhennia [Effect of arterial pressure control with the use of calcium channel blocker and differentrenin-angiotensin system inhibitors on central hemodynamics and arterial stiffness in patients with uncomplicated hypertension: results of six month's follow up]. Ukrainskyi medychnyi zhurnal Sertse i sudyny. 2016;(1):17-24. (In Ukrainian).
9. Sydorova LL. Ynhybytori anhyotenzynprevrashchaiushcheho fermenta pry lechenyy bolnikh s AH: problema vibora [ Inhibitors angiotensinconverting enzyme at treatment of patients with a AH: problem of choice]. Terapiia. 2017; (4): 13-18. (In Russian).

10. Rudenko YuV. Doslidzhennia efektyvnosti alhorytymizovanoi antyhipertenzyvnoi terapii v patsiientiv z neuskladnenoiu arterialnoiu hipertenziieiu zalezhno vid vykhidnykh pokaznykiv tsentralnoi hemodynamiky ta diastolichnoi funktsii livoho shlunochka [Efficiency estimation of antihypertensive therapy in patients with uncomplicated hypertension depending on initial indicators of central hemodynamics and diastolic left ventricular function]. Ukrainskyi medychnyi zhurnal Sertse i sudyny. 2016;(4):30-38. (In Ukrainian).

11. Radchenko GD, Mushtenko LO, Sirenko YuM. Rehres urazhennia orhanivmishenei na tli terapii fiksovanoiu kombinatsiieiu peryndoprylu ta amlodypinu v patsiientiv $z$ arterialnoiu hipertenziieiu zalezhno vid naiavnosti ishemichnoi khvoroby sertsia [Regression of the target organ damage under fixed dose combination perindopril/amlodipin in hypertensive patients with and without ischemic heart disease]. Ukrainskyi kardiolohichnyi zhurnal. 2017;(4):32-46. (In Ukrainian).

This research work is a fragment of the competitive state budget theme of the Department of Internal Medicine №3 of the National Pirogov Memorial Medical University, Vinnytsia on request of the Ministry of Health of Ukraine "Pathogenetic mechanisms of myocardial and endothelial dysfunction of vessels in heart diseases, arrhythmias and heart failure, and increase of efficiency and safety of treatment (clinical and experimental research)" (State registration number 0104U002883).

\section{ORCID and contributionship:}

Tetiana Y. Niushko - 0000-0002-5428-0621 A,B,C,D

Olena K. Tarasiuk - 0000-0002-7936-5381 D,E,F

Yulia K. Sikalo - 0000-0001-6740-9378 C,E,F

\section{Conflict of interest:}

The Authors declare no conflict of interest

\section{CORRESPONDING AUTHOR Olena K. Tarasiuk \\ National Pirogov Memorial Medical University, 56, Pirogova Str., 21018, Vinnytsia, Ukraine \\ tel: +380976902448 \\ e-mail: 0.k.tarasiuk@gmail.com}

Received: 27.04.2019

Accepted: 05.11.2019

A - Work concept and design, B - Data collection and analysis, C - Responsibility for statistical analysis, D-Writing the article, $\mathbf{E}$-Critical review, $\mathbf{F}$-Final approval of the article 